\title{
MODEL PEMBELAJARAN BAHASA BERBASIS TUGAS (PBBT) MELALUI PEMBELAJARAN DARING
}

\author{
Sulaiman \\ Universitas Trunojoyo Madura \\ Email: sulaiman@trunojoyo.ac.id
}

\begin{abstract}
Abstrak
PBBT is a language learning method that focuses on learners. In practice, PBBT is a language learning system that is focused on the task. Assignments given to learners are central to language teaching activities. In general the assignment of students can be said as a basic concept of PBBT. However, in this case the assignment of students at the beginning of learning becomes the hallmark of this method. With this method the teacher's role as a mediator, facilitator, and supervisor is more optimal. PBBT enables students to produce target languages through communicative task completion. The way PBBT works contains the following principles: (1) assignments must be designed to foster student motivation; (2) tasks must be accessed with information technology or the internet; and (3) assignments can foster student independence, tenacity, and honesty. In addition, the current learning process is not just a transfer of knowledge from teachers to learners, but has shifted through electronic media, be it computers, devices, and cellular phones that can be accessed anytime and anywhere according to the wishes of the learner. That as an effort to the presence of information technology and the internet must be utilized as well as possible to develop learning.
\end{abstract}

Kata-kata kunci: model, pembelajaran bahasa berbasis tugas, pembelajaran daring.

\section{PENDAHULUAN}

Keberadaan bahasa sejak dulu telah menantang para dosen (baik sebagai pengajar maupun peneliti) untuk melakukan telaah/penelitian terkait pendefinisian, penelaahan lebih luas, dan menemukan perbedaan-perbedaan dalam pembelajaran bahasa. Mereka diharapkan dapat membimbing mahasiswanya dan mendorong apresiasi mahasiswa terhadap keanekaragaman budaya dan identitas. Peneliti bahasa, juga ditantang dalam bidang akademik dan profesi. Mereka diharapkan dapat mempertahankan roadmap penelitian yang kuat, terpublikasi, diseminarkan, dan ditindaklanjuti untuk pengabdian masyarakat.

Saat ini kita telah memasuki era globalisasi dan perkembangan teknologi yang begitu pesat dan cepat. Era Revolusi Industri 4.0 sudah di depan mata kita. Suka atau tidak, kita harus hadapi era tersebut. Tentunya dengan menyiapkan diri dengan sebaik-baiknya. Kita dapat bertindak dan berbuat sesuai perkembangan zaman sehingga kita tidak tergilas olehnya. Oleh karena itu, perlu dilakukan reformasi di segala bidang, khususnya bidang pendidikan dan pembelajaran. Pembelajaran harus dapat memfasilitasi pembentukan insan yang unggul, cerdas, trengginas, memiliki empati dan spiritual yang bagus, berkarakter dan berdaya saing tinggi.
Dosen sebagai agen pembelajaran perlu memfasilitasi mahasiswa agar kapasitas belajar dan keterampilan mahasiswa dapat ditingkatkan. Kapasitas belajar mahasiswa yang tinggi merupakan modal sukses dan memudahkan mahasiswa dalam memperoleh pengetahuan, wawasan, dan keterampilan. Hal-hal tersebut akan meningkatkan kompetensi mahasiswa. Sedikitnya lima keterampilan mahasiswa yang harus dikembangkan dalam pembelajaran, yaitu: berpikir kritis, kreatif, inovatif, kolaboratif, dan komunikatif. Dosen bukan sekadar memberi informasi ke pikiran mahasiswa, tetapi harus mendorong mahasiswa mengeksplorasi, menemukan pengetahuan, merefleksi, dan berpikir kritis. Dengan demikian, belajar tidak hanya menghafal dan memahami materi saja, tetapi juga memberi dan menciptakan peluang untuk membangun pengetahuan dan pemahaman materi pembelajaran lebih lanjut.

Proses belajar, saat ini tidak hanya sekadar transfer ilmu dari pengajar ke pembelajar, tetapi telah beralih melaui media elektronik, baik itu komputer, gawai, dan telepon selular yang dapat diakses kapanpun sesuai keinginan. Bergesernya pola belajar ini membuat akademisi berlomba-lomba untuk menyajikan materi belajar dengan memanfaatkan media teknologi informasi yang dapat diakses dengan 
mudah dengan fasilitas internet. Kehadiran teknologi informasi dan internet harus dimanfaatkan dengan sebaik-baiknya untuk mengembangkan pembelajaran yang lebih bermutu.

\section{KAJIAN PUSTAKA}

Hal yang serupa dengan model pembelajaran PBBT, kali pertama dikemukakan oleh Prabu (1987) dengan model task based learning yang memiliki tiga kegiatan utama yaitu: pre-task (preparatory), task (meaning focused and interactive process), dan post task (attending to form). Hal pertama yang dilakukan adalah persiapan, kemudian kedua, proses penugasan (berarti fokus dan proses interaktif). Dalam hal ini mahasiswa harus menyelesaikan tugas yang diberikan dosen. Dalam penyelesaian tugas tersebut, antara dosen dan mahasiswa atau antarmahasiswa dapat melakukan secara interaktif. Langkah ketiga adalah memposting atau menyebarkan hasil penugasan. Kegiatan yang dapat dilakukan adalah dengan menempel/mengumumkan hasil penugasan di mading atau di dalam kelas yang sudah disiapkan lebih dulu sarananya. Dengan demikian mahasiswa dapat melihat hasil pekerjaan temannya. Dalam proses ini juga terjadi interaksi antarmahasiswa dengan melihat pekerjaan temantemannya. Dengan demikian, secara tidak langsung mahasiswa dapat mengukur hasil pekerjaannya dibandingkan pekerjaan temantemannya.

Berkaitan dengan hal di atas, model tersebut kemudian dikembangkan lagi oleh Willis (1996) menjadi enam langkah yaitu: pre task (input, focus on meaning), task, assess task, planning, task presentation, post task language focus). Pertama, tugas awal (masukan, fokus pada makna), kegiatan yang dilakukan adalah menyiapkan materi penugasan yang difokuskan pada makna. Kedua, pemberian tugas atau penugasan pada mahasiswa. Ketiga, tugas menilai. Kegiatan penilaian dapat dilakukan dosen dengan melihat hasil pekerjaan mahasiswa. Penilaian juga dapat dilakukan antarmahasiswa dengan memberikan tanggapan, kritikan, masukan atas pekerjaan mahasiswa lain atau dosen bersama-sama dengan mahasiswa melakukan penilaian. Keempat, merencanakan penugasan. Kelima, presentasi tugas, yaitu mahasiswa mempresentasikan hasil pekerjaannya. Keenam, memposting hasil penugasan.
Beberapa temuan terbaru telah dilakukan oleh para peneliti diantaranya adalah Jeon dan Hann (2006) yang menfokuskan pada persepsi tentang Task Based Language Teaching (TBTL) pada guru dan siswa sekolah menengah pertama di korea yang belajar General English. Hasil penelitian tersebut menunjukkan bahwa pembelajar memiliki persepsi yang baik terhadap implementasi TBTL. Sementara itu, Branden (2011) menjelaskan bahwa task based language teaching mensyaratkan pembelajar lebih aktif dan memiliki peran utama dalam pembelajaran. Pembelajar harus diberi peran dan tanggung jawab yang sama, termasuk dalam menyiapkan materi dan pilihan materi pembelajaran. Pembelajar terlibat berlangsung dan menunjukkan performa yang bagus dalam pembelajaran. Di samping itu, pembelajar dilibatkan dalam membahas berbagai aspek penerapan dan evaluasinya. Peran guru/dosen adalah memotivasi secara alami dan selalu memberi dorongan penuh kepada para pembelajar.

Pembelajaran Bahasa Berbasis Tugas (Task-Based Language Teaching) merupakan metode pengajaran bahasa yang menggunakan tugas-tugas sebagai unit inti untuk merencanakan dan menyusun bahan/materi dalam pembelajaran bahasa (Richards \& Rodgers, 2001: 223). Dengan kata lain, pertama, pengajaran bahasa adalah penggunaan tugas-tugas sebagai cara untuk mencapai tujuan pengajaran. Berdasarkan definisi tersebut, PBBT menekankan pada perolehan makna bahasa daripada perolehan aturan (bentuk) bahasa. Kedua, tugas mengharuskan pembelajar memperoleh kemampuan komunikatif sebagai tujuan dan hasil belajar. Ketiga, tugas meningkatkan kemampuan linguistik melalui konteks komunikasi alamiah. Keempat, tugas dirancang sebagai kegiatan kelas yang berhubungan dengan kegiatan keseharian.

\section{PEMBAHASAN}

\section{Pembelajaran Bahasa Berbasis Tugas (PBBT)}

PBBT merupakan metode pembelajaran bahasa yang menggunakan seperangkat tugas sebagai kegiatan inti untuk merencanakan, menyusun bahan/materi dan aplikasi dalam pembelajaran bahasa. Penugasan menjadi pokok utama pembelajaran bahasa untuk mencapai tujuan pembelajaran. Nunan (2004:1) membedakan tugas dalam dua jenis, yaitu: tugas sebagai target dan tugas pedagogik. Tugas sebagai target mengacu pada penggunaan bahasa 
dalam kegiatan sehari-hari di luar ranah pembelajaran, sedangkan tugas pedagogik mengacu pada penggunaan bahasa dalam pembelajaran di kelas yang berbentuk tugas atau latihan di dalam kelas. Sementara itu, Skehan (1998) dalam Ellis (2000) menyatakan bahwa tugas pedagogik sebagai suatu rencana kerja (belajar) memiliki empat karakteristik utama. Pertama, makna dari bahasa yang diekspresikan itu penting dan jadi prioritas. Kedua, ada tujuan yang harus dicapai dari tugas yang diberikan. Ketiga, rancangan kegiatan belajar atas tugas yang diberikan harus bisa dievaluasi hasilnya. Keempat, rancangan kegiatan belajar harus berhubungan dengan kegiatan keseharian. Keempat karakteristik tersebut secara jelas memberi penekanan pada perolehan makna dari bahasa yang digunakan harus sesuai dengan konteks dan berkaitan dengan kehidupan nyata.

Pembelajaran berbasis tugas telah dipakai sebagai satu metode dalam pembelajaran. Banyak dosen yang sudah mempratikkan pembelajaran dengan berbasis tugas. Bahkan telah ditulisnya dalam bentuk artikel dan dijurnalkan. Zakime (2018) menjelaskan dengan istilah TBL (Task Based Learning) atau TBLT (Task Based Learning and Teaching) adalah sebuah pendekatan di mana pembelajaran berputar di sekitar penyelesaian tugas yang bermakna. Dalam pendekatan TBL, fokus utama adalah penggunaan bahasa otentik untuk komunikasi asli. Lebih lanjut dijelaskan tentang pendefinisian tugas, fase yang mungkin dari pelajaran TBL dan memberi contoh pembelajaran TBL.

Sementara itu, Boston (2010) dalam PreTask Syntactic Priming and Focused Task Design memaparkan pemberian tugas dalam bentuk presentasi eksplisit. Dalam laporannya bahwa tugas fokus yang ia gunakan dan tugas narasi gap-gap tidak menghasilkan upaya penggunaan struktur target (suara pasif). Kegagalan ini mencerminkan kesulitan memastikan bahwa tugas yang terfokus membuat penggunaan struktur yang ditargetkan 'penting' sebagai lawan dari hanya 'berguna' atau 'alami'. Dalam hal ini melihat pembelajaran bahasa dari perspektif pemrosesan informasi, di mana akurasi dan kompleksitas bersaing untuk mendapatkan perhatian.

Robinson (2011) dalam Task-based learning: A review of Issue menyatakan bahwa secara teori, penelitian empiris yang termotivasi dalam pembelajaran bahasa berbasis tugas telah didorong oleh proposal untuk pengajaran bahasa berbasis tugas. Pembelajaran berbasis tugas dapat merangsang proses akuisisi dan rasional teoretis yang telah memandu penelitian ke dalamnya. Adapun taksonomi karakteristik tugas yang telah diusulkan tentang efek karakteristik tugas pada interaksi, perhatian terhadap input, dan produksi suara. Selanjutnya, dikaitkan masalah yang diangkat dengan temuan yang dijelaskan dalam lima studi empiris dalam masalah ini mengenai efek desain tugas pedagogik pada akurasi, kelancaran, dan kompleksitas bahasa pelajar. Pengaruh perbedaan individu dalam variabel kognitif dan motivasi terhadap kinerja tugas; sejauh mana tugas, dan intervensi guru, mempromosikan kuantitas dan kualitas interaksi yang memfasilitasi pembelajaran bahasa dan generalisasi dari penelitian pembelajaran berbasis tugas dalam konteks laboratorium untuk menginstruksikan pengaturan ruang kelas.

\section{Pembelajaran Daring}

Kehadiran teknologi informasi dan komunikasi berdampak positif dalam berbagai aspek kehidupan, tidak terkecuali pada aspek pendidikan. Kita sangat dimudahkan memperoleh pengetahuan atau wawasan dari media online. Banyaknya sumber yang tersebar di media online memungkinkan kita dapat mengaksesnya melalui gawai, smartphone, smarttv, dan media lain yang berbasis internet. Perkembangan itu telah dimanfaatkan oleh banyak perguruan tinggi di Indonesia dalam penyelenggaraan program pendidikannya. Program tersebut dikenal sebagai program pembelajaran daring atau sistem $e$ learning/online learning.

Thomas dan Reinders (2011) menyatakan bahwa sesuai dengan tuntutan perkembangan information dan teknologi maka kebutuhan pengembagan task based teaching and learning harus sudah berkaitan dengan CALL (Computers Assisted Language Learning). Kebutuhan integrasi CALL dalam task based learning ini adalah bagian dari tuntutan pembalajar dan dunia informasi. Oleh karena itu desain dan materi pembelajaran harus mencerminkan tuntutan tersebut, terutama kesiapan dosen sebagai perancang kurikulum. Sebagaimana yang telah diteliti bahwa technology mediated task based approach telah memberikan dampak yang signifikan terhadap pembelajar khususnya para mahasiswa yang sedang belajar bahasa Inggris di universitas di Jepang. Selanjutnya para mahasiswa sangat termotivasi untuk belajar 
bahasa Inggris bila perangkat pembelajaranya berdekatan dengan teknologi informasi.

Pembelajaran daring dapat dipahami sebagai pendidikan formal yang diselenggarakan oleh perguruan tinggi. Pembelajaran daring bisa berlangsung meski mahasiswa dan dosen, sebagai instrukturnya berada di lokasi terpisah. Pembelajaran bisa berlangsung secara interaktif sehingga memerlukan sistem telekomunikasi untuk menghubungkan keduanya dan berbagai sumber daya yang diperlukan di dalamya. Bahkan, pemerintah telah memiliki sistem pembelajaran daring yang disebut dengan SPADA (Sistem Pembelajaran Daring) Indonesia. Kehadiran SPADA Indonesia diharapkan dapat mengimplementasikan pendidikan jarak jauh yang bertujuan untuk meningkatkan pemerataan akses pembelajaran yang bermutu. Hal ini sangat dimungkinkan karena SPADA Indonesia memberikan peluang bagi mahasiswa dari satu perguruan tinggi tertentu untuk dapat mengikuti suatu mata kuliah bermutu tertentu dari perguruan tinggi lain dan hasil belajarnya dapat diakui sama oleh perguruan tinggi di mana mahasiswa tersebut terdaftar.

SPADA Indonesia menawarkan tiga program unggulan, yaitu: materi terbuka, materi kuliah terbuka, dan mata kuliah daring. Pertama, materi terbuka, yaitu menyediakan materi mata kuliah yang disajikan secara online dalam berbagai bentuk media agar dapat diakses oleh mahasiswa dan dosen kapan saja dan dimana saja. Kedua, mata kuliah terbuka, yaitu sistem pembelajaran daring satu mata kuliah utuh yang memungkinkan untuk dapat digunakan oleh dosen terkait sebagai mata kuliah daring untuk diselenggarakan dalam pembelajaran. Ketiga, mata kuliah daring, yaitu mata kuliah dalam bentuk pembelajaran daring utuh, yang siap ditawarkan oleh salah satu PT penyelenggara kepada PT lain (PT mitra) untuk dapat diikuti oleh mahasiswa PT mitra sebagai wahana alih kredit (credit transfer) dan nilai yang diperoleh mahasiswa dari PT penyelenggara dapat ditransfer (credit transfer) di PT di mana mereka terdaftar.

Sistem pendidikan jarak jauh ini sebenarnya bukanlah hal yang baru pada sistem pembelajaran kita. Universitas Terbuka (UT) merupakan PTN yang sejak awal mempraktikkan pembelajaran daring. Bahkan hampir semua provinsi memiliki kantor wilayah, yang lebih dikenal dengan UPBJJ. Hal tersebut juga dinyatakan Salwa (2019) bahwa pembelajaran jarak jauh yang diselenggarakan oleh Universitas Terbuka memberikan banyak manfaat dan peluang bagi mahasiswa di daerah terpencil untuk mendapatkan layanan pendidikan tinggi. Untuk saat ini, program pembelajaran ini difasilitasi oleh program bantuan e-learning menggunakan teknologi dan media informasi. Proses pembelajaran ini menekankan materi yang tidak terbatas untuk mahasiswa di luar sumber utama, yang dapat diakses kapan saja dan di mana saja. Artikel ini mencoba memberikan pandangan baru dalam Tutorial Online tentang teknik atau model yang dapat diterapkan. Model ini mencakup praktik, dan tugas yang dapat dilakukan secara mandiri oleh mahasiswa. Model pembelajaran ini akan meningkatkan dan membangun pembelajaran mandiri mahasiswa dengan memberi mereka tugas yang otentik tetapi sederhana, tugas praktis dan mandiri.

\section{Pembelajaran Bahasa Berbasis Tugas (PBBT) melalui Pembelajaran Daring}

Layanan pendidikan dituntut untuk terus berinovasi seiring dengan perkembangan teknologi informasi dan komunikasi terkini. Hanya berbekal gadget atau gawai generasi sekarang dapat belajar di mana saja dan kapan saja tanpa memerlukan tatap muka dengan instruktur atau dosennya. Kemajuan teknologi ini sangat membantu dalam pembelajaran, khususnya PBBT. Dengan pembelajaran daring, PBBT dapat dilakukan dengan mudah meski tidak harus dengan tatap muka, baik pada saat pemberian tugas maupun penerimaan tugas sebagai laporan kegiatan yang telah dilakukan oleh mahasiswa.

Banyak hal yang telah diterapkan pada pemberian tugas sebagai kegiatan untuk pembelajaran bahasa. Yang terpenting adalah penekanan pada komunikasi dan penyelesaian. Pemberian tugas harus mengkomunikasikan informasi untuk membuat keputusan, menyelesaikan masalah, dan mencapai hasil. Mereka harus akurat dan komprehensif dalam berkomunikasi. Suatu tugas dianggap selesai jika ada keputusan, masalah diselesaikan, dan hasil dicapai.

Metode pemberian tugas dapat dilaksanakan oleh dosen. Tugas pemecahan masalah, misalnya, dapat berasal dari pembelajaran daring atau panduan bentuk lain yang didaringkan. Dosen dapat memberikan tugas kepada mahasiswa, baik secara individu 
maupun kelompok dan memastikan informasi yang diperlukan terdistribusi dengan baik melalui media online. Dosen juga harus memastikan bahwa bahan/materi yang didaringkan juga mudah diakses oleh mahasiswa. Dengan demikian PBBT melalui pembelajaran daring dapat berjalan dengan baik.

Tugas yang diberikan harus otentik dan sesuai tujuan para mahasiswa dalam pembelajaran bahasa. Tugas tidak dapat dianggap sebagai tes atau instrumen penelitian. Tugas tersebut harus dapat menarik minat mereka dan melakukannya dalam jangka panjang. Berbagai tugas harus digunakan untuk menghindari efek monoton yang mungkin dimiliki oleh satu jenis tugas terhadap minat dan perhatian mahasiswa. Tugas-tugas juga harus diintegrasikan ke dalam konten kurikulum. Dengan demikian, dianggap sesuai dengan tujuan dan minat mahasiswa.

Tugas yang dirancang dari teks tertulis adalah otentik untuk kurikulum, kursus, atau kelas berbasis konten karena tugas membaca dan menulis biasanya diberikan kepada mahasiswa dalam konteks ini. Untuk lebih memajukan keaslian tugas, mahasiswa dapat didorong untuk melihat hubungan antara melaksanakan tugas dan mencapai tujuan akademik, profesional, atau pekerjaan yang lebih besar. Tugas kelas harus dirancang dengan mempertimbangkan kondisi ini. Mereka harus mudah diproduksi dan diimplementasikan, dengan arahan yang mudah diikuti. Format mereka harus dapat disesuaikan dengan produksi tugas baru sehingga desain tugas yang diselesaikan dapat berfungsi sebagai tempat untuk tugas di masa depan.

Aturan dasar pembelajaran bahasa adalah peserta didik dapat menginternalisasi bentuk dan fitur yang siap untuk dipelajari perkembangannya. Namun, item-item yang sulit diketahui ini tidak berkembang dalam urutan dan tahapan, seperti halnya untuk item yang terdiri dari pengembangan pertanyaan. Sebagai gantinya, konteks untuk penggunaannya muncul pada awal perkembangan pembelajar. Oleh karena itu, kehadiran pembelajaran daring dapat dimanfaatkan dengan maksimal dalam PBBT, khususnya memudahkan penyajian bahan/materi, perluasan akses pembelajar, dan memudahkan para mahasiswa mendapatkan informasi yang sebanyak-banyaknya.

Mengaktifkan proses pembelajaran daring telah menjadi tujuan mulia para dosen. Di samping itu, pemberian tugas melalui pembelajaran daring memberikan peluang penting bagi mahasiswa untuk mendapatkan informasi secara cepat dan akurat. Hal itu juga sebagai upaya mencapai hasil belajar yang maksimal, hasil belajar yang sangat dinginkan mahasiswa dan dosen. Namun, hal itu tidak mudah dilakukan karena membutuhkan komitmen antara dosen dan mahasiswa. Harus ada kepercayaan dengan kewajiban dan tanggung jawab masing-masing. Para dosen dan mahasiswa akan mendapatkan informasi yang memadai, lebih profesional, dan terlihat relevan satu sama lain. Dengan demikian, akan muncul peluang untuk kolaborasi dan kerja sama yang lebih besar. Selama dosen dan mahasiswa menemukan cara untuk bekerja bersama di kelas, dan tetap berkomitmen untuk hubungan jangka panjang dengan pelajar bahasa, selalu ada arahan dan harapan bagi mahasiswa untuk lebih baik dari sebelumnya dalam pembelajaran bahasa.

\section{SIMPULAN}

Artikel ini dimulai dengan menggambarkan tantangan yang dihadapi para dosen sekaligus sebagai peneliti dalam pembelajaran bahasa. Beberapa hubungan yang paling bermanfaat telah dibangun oleh para dosen dan mahasiswa dalam pembelajaran bahasa. Para dosen telah melihat keprihatinan mereka tentang strategi pembelajaran bahasa di kelas. Kegiatan yang dirancang telah diadaptasi untuk praktik pembelajaran. Hal inilah mengungkapkan caracara di mana para dosen dan mahasiswa dapat bekerja sama untuk mengembangkan tugas-tugas yang sesuai dengan kebutuhan dan gaya mahasiswa beserta dosennya.

Model pemberian tugas bukanlah hal baru dan asing pada pembelajaran kita. Bahkan di Universitas Terbuka, model pemberian tugas menjadi yang utama dan sangat dominan. Bantuan belajar tutorial online yang dapat dimanfaatkan oleh Mahasiswa UT seharusnya menjadi media belajar bagi mahasiswa untuk membangun proses belajar mandiri, kreatif, dan inovatif. Proses belajar ini tidak akan melekat sempurna apabila tidak disertai dengan praktik dan aplikasi belajar secara riil yang dilakukan oleh mahasiswa. 


\section{DAFTAR PUSTAKA}

Boston, J. 2010. Pre-Task Syntactic Priming and Focused Task Design. ELT Journal, 64: $165-174$.

Ellis, Rod. 2000. Task-Based Research and Language Pedagogy. Language Teaching Research vol. 4 (3), pp. $193-220$.

Jeon, In-Jae and Hahn, Jung-won. 2006. Exploring EFL Teachers' Perceptions of Task-Based Language Teaching: A Case Study of Korean Secondary School Classroom Practice. Mokpo: Mokpo National University, Korea.

Nunan, David. 2004. Task-Based Language Teaching. Cambridge: Cambridge University Press.

Prabhu, N. 1987. Second Language Pedagogy. Oxford: Oxford University Press.

Richards, Jack.C. and Rodgers, Theodore S. 2001. Approaches and Methods in Language Teaching. (2nd ed). Cambridge: Cambridge University Press. Sánchez, Aquilino. 2004. The TaskBased

Robinson, P. (2011). Task-based learning: A review of Issue. Language Learning. Tokyo: A Journal of research in language studies, 61(sl), 1- 36.

Salwa, Athiyah. (2019). Model Task-Based Learning untuk Membangun Pembelajaran Mandiri Pada Tutorial Online. Jurnal Pendidikan Terbuka dan Jarak Jauh, Volume 20, Nomor 1, Maret 2019, 10-16.

Thomas, Michael and Reinders, Hayo.2011. Task-Based Language Learning and Teaching with Technology. Language Learning and Technology, October 2011, Volume 15, Number 3 pp. 3236.

Willis, J. 1996. A Framework for Task-Based Learning. Edinburgh: Addison Wesley.

Zakime, Andreia. (2018). What is Task Based Learning? Available at: https://www.whatiselt.com, acssesed 29 Mei 2018. 